\title{
Who lends to riskier and lower-profitability firms? Evidence from the syndicated loan market
}

\author{
Maria Iosifidi $^{\mathrm{a}, *}$, Sotirios Kokas ${ }^{\mathrm{b}}$ \\ a Surrey Business School, University of Surrey, Guildford GU2 7XH, UK \\ ${ }^{\mathrm{b}}$ Essex Business School, University of Essex Wivenhoe Park, Colchester CO4 3SQ UK
}

\section{A R T I C L E I N F O}

\section{Article history:}

Received 11 August 2014

Accepted 3 February 2015

Available online $\mathrm{xxxx}$

\section{JEL classification:}

G20

G21

G30

G32

\section{Keywords:}

Bank-firm relationships

Risk

Performance

Syndicated loans

\begin{abstract}
A B S T R A C T
This paper exploits a unique data set on bank-firm relationships based on syndicated loan deals to examine the effect of banks' credit risk and capital on firms' risk and performance. Our data set is a multilevel cross-section, which essentially allows controlling for all bank and firm characteristics through respective fixed effects, thus avoiding concerns regarding omitted variables. We find that banks with higher credit risk are associated with more risky firms, with lower profitability and market value. In turn, we find that banks with higher risk-weighted capital ratios lend to riskier firms with less market value. Our results are indicative of a strong adverse selection mechanism and highlight the need to monitor the risky banks more closely, especially as we consider large and influential syndicated loan deals.
\end{abstract}

(c) 2015 Elsevier B.V. All rights reserved.

\section{Introduction}

What are the characteristics of banks that lend to firms with relatively high risk and low performance? The answer to this question has fundamental implications for the understanding of the bank-firm relationship lending, financial stability and real macroeconomic outcomes. Surprisingly, despite the presence of a prominent literature on relationship lending, this issue has been underresearched. In this paper, we aim to fill this gap in the literature by empirically analyzing the relation between firm risk and performance on the one hand, and bank capital and credit risk on the other.

The main proposition of our analysis is that banks with differential levels of credit risk and capital will be associated with firms with differential risk and performance. Specifically, risky and less profitable firms can have a difficult time obtaining credit from banks with relatively low levels of credit risk in their portfolios (risk-averse banks). In turn, banks with higher levels of credit risk are usually inclined to lend to more risky and less profitable firms (Peek and Rosengren, 2005). Thus, causality in this type of bankfirm relationship runs in both directions. The end result is one of

\footnotetext{
* Corresponding author.
}

a special type of cherry-pick, where the financially healthy banks are associated with financially healthy firms and the less healthy banks are associated with the less profitable firms (Jones et al., 2005).

The possible role of bank capital in the nexus between banks and firms is less straightforward. On the positive side, banks with higher capital ratios are those with more prudent behavior in all their activities, including lending to less risky and profitable firms (Diamond and Rajan, 2000, 2001; Gorton and Winton, 2000). On the negative side, a high capital ratio is a strong safety net for bank managers, who therefore face increased incentives to lend to risky borrowers that the bank would not be associated with if the level of capital was lower (Dahl and Shrieves, 1992; Bhattacharya and Thakor, 1993; Repullo, 2004; Murfin, 2012).

We test the presence of these bank-firm relationships using data from the syndicated loan market. This market is ideal for our empirical tests because it usually involves large, systemically important banks and firms and it is a relatively competitive market. Thus, we expect that the results in other more traditional bank-firm relationships would be even more pronounced if present in the syndicated loan market. Moreover, the data from the syndicated loan market have a unique characteristic. They represent the only source of information at the loan-level, with additional information on who is the lender (the lead bank-arranger 
of the loan) and who is the borrower (firm). This allows the matching of these data with information on the bank and firm characteristics, which are invaluable in the empirical examination of the question "who lends to risky and non-performing firms."

To this end, we build a unique data set on loan, bank, and firm characteristics, and analyze the nexus between firm risk and performance, and bank credit risk and capitalization. Theoretically, the direction of the causality in our analysis is not an issue. We aim to identify the nature of the bank-firm relationships and not which of the two parties initiates this relationship. However, a potential bias in our estimates may come from omitted variables bias, as there are many unobserved reasons behind the choice to lend to a specific firm or borrow from a specific bank. On this front, the structure of our sample has the additional merit that is a multilevel cross-sectional data set, with the different levels stemming from the fact that the same bank has given many loans in each time period and the same firm has obtained more than one loans within the same period. This allows including both bank and firm fixed effects, which effectively eliminate the omitted variables bias in our empirical models.

Our results show that banks with high credit-risk ratios are strongly associated with firms with high profit volatility, lower market value, and lower profitability. With small modifications, these findings hold irrespective of the variables used to proxy the credit risk of banks and are economically significant. Specifically, a $1 \%$ point increase in our preferred measure of bank credit risk is associated with an increase in the volatility of the return on assets for the mean firm from 0.022 to 0.026 and a decrease in the risk-adjusted returns of the mean firm from 20.3 to 14.5 . These results reveal a disconcerting affiliation of risky banks with risky firms, yielding a bad equilibrium in the market for credit. Given that this equilibrium is observed in the syndicated loan market, which brings together relatively large banks and firms, this can be a recipe for a turmoil in both the banking (and by extension in financial) and the products markets.

The role of bank capital in defining the bank-firm relationships is also quite important for the bank-firms relationships. We find that banks with high risk-weighted capital ratios are associated with firms with high volatility of returns and low market value. These findings are in line with the idea that overcapitalized banks will tend to take on higher risk in search for yield, which is in line with the adverse selection and moral hazard mechanisms of the capital-regulation theory (Hellmann et al., 2000). We contend that our results have important implications for prudential regulation in light of the recent revisions under the impulse of Basel III.

The rest of our paper is structured as follows. Section 2 analyzes the theoretical links between firm risk and performance, and bank credit risk and capital. Section 3 discusses the data and the variables used in the empirical analysis. Section 4 discusses the empirical identification method and presents the empirical results. Section 5 concludes with the policy implications of our findings.

\section{Theoretical considerations}

The literature on relationship lending highlights a number of beneficial effects of close bank-firm relationships. The most notable of these effects are the alleviation of liquidity constraints of firms due to the reduction in adverse selection and moral hazard problems and the longer-term horizon of investment decisions (e.g., Rajan, 1992; Hoshi et al., 1991). However, a more recent strand of this literature also highlights some wrinkles in the beneficial effects of relationship lending. For example, Giannetti (2003) shows that banks can renew lending to insolvent projects and accumulate losses, which leads to increased probability of bank insolvency and financial instability.

The seminal paper on the theory of the selection of borrowers by banks is the one by Stiglitz and Weiss (1981). In this model, banks are unable to observe the exact riskiness of borrowers, thus they offer the same type of loan contracts to all firms. One problem with this modelling framework is that, in the real world, bank managers tend to cherry-pick borrowers based on specific screening devices such as collateral (e.g. Bester, 1985). This immediately suggests that banks have a clear view about the different risk levels of potential borrowers, especially as informational asymmetry problems decrease.

The opposite argument concerning the decisions of banks with different level of capital and credit risk to lend to healthy or less healthy firms is quite under-researched. The theoretical debate on this front can be traced in the work of Peek and Rosengren (2005) for the misallocation of credit to relatively weak firms. In a world with relatively lax regulatory supervision, banks follow a policy of forbearance with the troubled borrowers to avoid increasing their own loan-loss reserves, which will impair their capital ratios. Subsequently, the risky banks will be incentivized to extend their line of credit to troubled borrowers, so as to enable these borrowers to make interest payments on outstanding credit.

This line of reasoning also works in the opposite direction as well, from troubled firms to the worse-performing banks. The less profitable and risky firms will have a tough time borrowing from a healthy bank, which is likely to have superior managerial and monitoring capacity as a means to reduce adverse selection and moral hazard in the lending process. Thus, these firms are likely to turn to less risk-averse banks, which have a history of lending to riskier firms. These banks will likely be characterized by higher levels of non-performing loans and loan-loss provisions, information which is ex post disclosed to the public on a quarterly basis. Thus, we expect that risky (worse performing) firms are likely to be affiliated with risky banks and vice versa, especially when we call risky banks those with a relatively high amount of credit risk in their portfolios.

The proposition on the relationship between risky banks and risky firms is a special type of a more hazard problem, which however has some element of adverse selection in that the problem precedes the loan deal. Thus, we are referring here to a variant of the Akerlof (1970) - type lemon's problem, whereby the low-quality firms will be left to choose the low-quality banks and vice versa, even if information is complete. This state of affairs creates a vicious cycle with an association of low quality firms and banks, which for markets as important as the syndicated loan market can be a recipe for banking instability.

In contrast, the role of capital in the banks' decision to lend to relatively riskier and lower-profitability firms is usually studied within the theoretical bank capital regulation literature. This literature makes contradicting predictions about the role of bank capital. Diamond and Rajan (2000), Diamond and Rajan, (2001) and Gorton and Winton (2000) propose a number of mechanisms (quoted as financial fragility mechanisms) through which higher bank capitalization reduces lending and, thus, credit risk. The highlight of this influential literature is that bank capital diminishes the financial fragility that facilitates the lending process and will "crowd out" deposits. The resulting effect is a safer banking system through the reduction of the credit risk of banks. However, this literature is, in general, silent on the type of firms that the wellcapitalized banks tend to be associated with.

The opposite result is established by giving bank capital the role of risk buffer, which expands banks' risk-bearing capacity (e.g. Bhattacharya and Thakor, 1993; Repullo, 2004). In this framework, the well-capitalized banks have increased incentives to extend their credit to relatively risky borrowers, because holding too 
much capital bears an important opportunity cost. In fact, most empirical studies (e.g., Jokipii and Milne, 2011; Dahl and Shrieves, 1992) document a positive relationship between capital buffers (i.e., the distance of the actual level of capital from its regulatory minimum) and bank risk. Further, the recent paper of Murfin (2012) shows that well-capitalized banks tend to write looser contracts with their borrowers, while reductions in equity capital will lead to stricter contracts. This effect is consistent with the idea that undercapitalized banks are more cautious in their risk-taking strategies to shield their already low levels of capital from further deterioration.

It becomes quite apparent, that the role of capital in the bankfirm relationships is ambiguous. If banks operate under the financial-fragility mechanism, then they will curtail lending especially to the more risky firms. If banks operate under the capacity mechanism, which seems to be the dominant mechanism in the existing empirical literature, they will possibly expand their risky activities to firms with less healthy balance sheets.

On the basis of the above theoretical considerations and empirical facts we can formulate the following two testable hypotheses:

H1. Banks with higher credit risk will be associated with more risky and worse-performing firms.

H2. The better capitalized banks will most probably be associated with more risky and worse-performing firms.

\section{Data}

In the empirical analysis we aim to identify the characteristics of banks, in terms of capital and credit risk, that lend to risky and relatively poor-performing firms. Thus, we estimate an empirical model of the form:

$R_{f t}=f\left(F_{f t}, L_{l t}, B_{b t}, u_{f t}\right)$,

where $R$ is a measure of risk or performance of firm $f$ at the time of the loan origination $t$. In turn, $R$ is a linear function of a vector of firm characteristics $F$ that affect $R$, a vector of loan characteristics $L$, and a vector of the lead arranger's (lead bank's) characteristics $B$ that include the capital and credit-risk profile of the bank. Finally, $u$ is the stochastic disturbance, which for identification purposes includes both bank and firm fixed effects as we will further discuss below.

Our sample consists of US syndicated loan deals that occur at a specific point in time (year of the loan deal), which define the bank-firm relationships. We examine the characteristics, mainly risk and capital, of the lead arranger in relation with the risk and performance of the borrowing firm. We collect our data from three different sources, with the cross-sectional observations of bankfirm relationships spanning the period 2000-2012.

Our source for the syndicated loan deals is the Thomson Reuters' Thomson One Banker database. ${ }^{1}$ This database provides information on the loan deal's characteristics (amount, maturity, borrowing spread, performance pricing, etc.). Thomson One Banker also provides information for the members of the syndicate, the lead bank, and the firm that receives the loan. This allows matching the information from Thomson One Banker to the FDIC Call Reports, which is our second data source. With this matching process we obtain accounting bank data on a number of bank characteristics. These data are quarterly and we use the information on the date

\footnotetext{
${ }^{1}$ Most empirical studies on syndicated loans use the DealScan database. However, the Thomson One Banker database has also been used by a large number of studies as the source for syndicated loan deals and its coverage is very similar with that of DealScan for our sample period.
}

Table 1

Variable definitions and sources.

\begin{tabular}{|c|c|c|}
\hline Variable & Definition & Source \\
\hline \multicolumn{3}{|c|}{ Dependent variables } \\
\hline$\sigma(\mathrm{ROA})$ & $\begin{array}{l}\text { The variance of firm ROA, where ROA is the } \\
\text { ratio of profits before taxes to total assets } \\
\text { and } \sigma(\mathrm{ROA}) \text { is calculated over a rolling } \\
\text { window of } 12 \text { quarters }\end{array}$ & Compustat \\
\hline Market value & $\begin{array}{l}\text { Natural logarithm of the market value of } \\
\text { common stock of firms }\end{array}$ & Compustat \\
\hline Sharpe & $\begin{array}{l}\mathrm{ROA} / \sigma(\mathrm{ROA}) \text {, where ROA is the ratio of } \\
\text { profits before taxes to total assets and } \\
\sigma(\mathrm{ROA}) \text { is calculated over a rolling window } \\
\text { of } 12 \text { quarters }\end{array}$ & Compustat \\
\hline ROA & Ratio of profits before taxes to total assets & Compustat \\
\hline \multicolumn{3}{|c|}{ Firm-level explanatory variables } \\
\hline Firm size & $\begin{array}{l}\text { Natural logarithm of the dollar value of firms' } \\
\text { sales }\end{array}$ & Compustat \\
\hline Firm efficiency & Ratio of firm sales to total assets & Compustat \\
\hline Firm liquidity & Ratio of current assets to current liabilities & Compustat \\
\hline Firm age & Firm age in years & Compustat \\
\hline $\begin{array}{l}\text { Borrowing } \\
\text { spread }\end{array}$ & $\begin{array}{l}\text { All-in-one spread of the average firms' loan } \\
\text { deals }\end{array}$ & $\begin{array}{l}\text { Thomson } \\
\text { Reuters }\end{array}$ \\
\hline $\begin{array}{l}\text { General } \\
\text { covenants }\end{array}$ & $\begin{array}{l}\text { Dummy variable equal to one if the firm uses } \\
\text { general covenants in its loan deals and zero } \\
\text { otherwise }\end{array}$ & $\begin{array}{l}\text { Thomson } \\
\text { Reuters }\end{array}$ \\
\hline \multicolumn{3}{|c|}{ Bank-level explanatory variables } \\
\hline Bank capital & Ratio of total bank capital to total assets & $\begin{array}{l}\text { FDIC Call } \\
\text { Reports }\end{array}$ \\
\hline $\begin{array}{l}\text { Bank risk- } \\
\text { weighted } \\
\text { capital }\end{array}$ & $\begin{array}{l}\text { Ratio of risk-based bank capital to risk- } \\
\text { weighted assets }\end{array}$ & $\begin{array}{l}\text { FDIC Call } \\
\text { Reports }\end{array}$ \\
\hline $\begin{array}{l}\text { Bank Tier } 1 \\
\text { capital }\end{array}$ & $\begin{array}{l}\text { Ratio of Tier } 1 \text { bank capital to risk-weighted } \\
\text { assets }\end{array}$ & $\begin{array}{l}\text { FDIC Call } \\
\text { Reports }\end{array}$ \\
\hline $\begin{array}{l}\text { Bank non- } \\
\text { performing } \\
\text { loans }\end{array}$ & $\begin{array}{l}\text { Ratio of bank non-performing loans to total } \\
\text { loans }\end{array}$ & $\begin{array}{l}\text { FDIC Call } \\
\text { Reports }\end{array}$ \\
\hline $\begin{array}{l}\text { Bank loan-loss } \\
\text { provisions }\end{array}$ & $\begin{array}{l}\text { Ratio of bank loan-loss provisions to total } \\
\text { loans }\end{array}$ & $\begin{array}{l}\text { FDIC Call } \\
\text { Reports }\end{array}$ \\
\hline $\begin{array}{l}\text { Bank loan } \\
\text { charge-offs }\end{array}$ & $\begin{array}{l}\text { Ratio of bank net loan charge-offs to total } \\
\text { loans }\end{array}$ & $\begin{array}{l}\text { FDIC Call } \\
\text { Reports }\end{array}$ \\
\hline Bank size & Natural logarithm of total bank assets & $\begin{array}{l}\text { FDIC Call } \\
\text { Reports }\end{array}$ \\
\hline Bank Z-score & $\begin{array}{l}\text { (Bank ROA + Bank capital)/Bank } \sigma(\mathrm{ROA}) \text {, } \\
\text { where Bank ROA is the ratio of profits before } \\
\text { taxes to total assets and Bank capital is as } \\
\text { above }\end{array}$ & $\begin{array}{l}\text { FDIC Call } \\
\text { Reports }\end{array}$ \\
\hline \multicolumn{3}{|l|}{ Other variables } \\
\hline Crisis dummy & $\begin{array}{l}\text { Dummy variable equal to one for the years } \\
2007 \text { and } 2008 \text { and zero otherwise }\end{array}$ & $\begin{array}{l}\text { Own } \\
\text { calculations }\end{array}$ \\
\hline
\end{tabular}

of the loan deal to match the time dimension with the FDIC Call Reports. Our final data source is Compustat, which provides accounting data for the firms that received the loan. These data are invaluable to measure firms' performance and obtain other control variables in our estimated models.

The matching process of data from the three databases yields a maximum of 7362 observations (loan deals). However, the number of observations used for the regressions depends on the availability of data for the variables used in our empirical analysis. These observations comprise a so-called multilevel data set, which has observations on banks and firms (lower level) and loan deals (higher level). This is a unique feature that proves particularly helpful for econometric identification purposes. Table 1 formally defines all the variables used in the empirical analysis and Table 2 offers summary statistics. We discuss these variables in turn.

\subsection{Measures of firm risk and performance}

We use four measures of firm risk and performance that capture a variety of relevant aspects of firms. The first is the standard 
Table 2

Summary statistics.

\begin{tabular}{llllll}
\hline Variable & Obs. & Mean & $\begin{array}{l}\text { Std. } \\
\text { dev. }\end{array}$ & Min. & Max. \\
\hline$\sigma($ ROA $)$ & 3806 & 0.022 & 0.110 & 0.001 & 6.224 \\
Market value & 3408 & 6.897 & 2.132 & -0.864 & 12.468 \\
Sharpe & 3526 & 20.284 & 26.209 & -21.993 & 339.703 \\
ROA & 3704 & 0.121 & 0.111 & -2.004 & 0.766 \\
Firm size & 3824 & 6.890 & 1.915 & 0.003 & 12.410 \\
Firm efficiency & 3827 & 0.961 & 0.800 & 0.001 & 7.567 \\
Firm liquidity & 3185 & 1.800 & 1.608 & 0.059 & 36.508 \\
Firm age & 3982 & 20.933 & 16.799 & 1 & 59 \\
Borrowing spread & 7362 & 210.41 & 136.27 & 7.00 & 1200.0 \\
General covenants & 7362 & 1.286 & 1.604 & 0 & 1 \\
Bank capital & 7359 & 0.089 & 0.039 & 0.047 & 0.493 \\
Bank risk-weighted capital & 5259 & 0.114 & 0.035 & 0.001 & 0.376 \\
Bank Tier 1 capital & 5259 & 0.081 & 0.027 & 0.001 & 0.368 \\
Bank non-performing & 6019 & 0.016 & 0.017 & 0.000 & 0.091 \\
$\quad$ loans & & & & & \\
Bank loan-loss provisions & 7359 & 0.009 & 0.010 & 0.000 & 0.063 \\
Bank loan charge-offs & 7359 & 0.008 & 0.008 & 0.000 & 0.072 \\
Bank size & 7362 & 18.635 & 1.595 & 11.817 & 20.980 \\
Bank Z-score & 3032 & 1.578 & 1.795 & -40.893 & 7.702 \\
\hline
\end{tabular}

Notes: The table reports the number of observations, mean, standard deviation, minimum, and maximum of the variables used in the empirical analysis.

deviation of the return on assets $(\sigma \mathrm{ROA})$, which is a standard measure of firms' risk (e.g., Laeven and Levine, 2009). We calculate this measure using a rolling 12-quarter horizon of the returns on assets (ROA). The higher is the volatility of earnings, the higher the riskiness of the firm. The second dependent variable of our study is the natural logarithm of the firms' market value of common stock. This is a market-oriented measure of firm performance and, thus, it complements the accounting-based ratio by being more forwardlooking. ${ }^{2}$

Our third measure is the accounting-data equivalent of the Sharpe ratio (e.g., Robb and Watson, 2012; Delis et al., 2014). We calculate this ratio using the book value of ROA over $\sigma(\mathrm{ROA})$, the latter again calculated using a 12-quarter horizon. This ratio measures the risk-adjusted returns of each firm at each point in time. By discounting the returns on assets, we provide a cleaner measure of returns, which is directly comparable across industries with inherently different levels of risk. The last measure of firm performance is the simple ROA, which is the most standard measure of firm performance in the corporate performance literature (e.g., Adams and Ferreira, 2009; Hitt et al., 1997).

\subsection{Measures of bank credit risk and capital}

We use three variables to measure each of ex post bank credit risk and capital. For credit risk, we use the ratios of non-performing loans to total loans, loan-loss provisions to total loans, and loan charge-offs to total loans (see e.g., Grier, 2007). Consistent with our theoretical considerations, all these measures are ex post measures of bank credit risk, while they complement each other in a number of ways.

Specifically, non-performing loans differ from loan charge-offs in that the former are assets that are past due 90 days or more as to principal or interest, or where reasonable doubt exists as to timely collection. In contrast, loan charge-offs occur when a loan is de facto an irrecoverable bad loan. The pairwise correlation coefficient between the two ratios in our sample is equal to 0.77 . In

\footnotetext{
${ }^{2}$ An alternative measure to the log of the market value would be Tobin's $q$; however, a recent literature suggests that Tobin's $q$ is an endogenous measure of performance. Specifically, Dybvig and Warachka (2013) criticize Tobin's $q$ on the basis that scale inefficiency due to underinvestment lowers firm performance but increases
} Tobin's $q$. turn, provisions for loan losses are somewhat more forward looking, as it represent the expense set aside by the bank for loan defaults (charge-offs). Thus, loan-loss provisions are very highly correlated with loan charge-offs, as the bank assigns a value for provisions approximately equal to the loans written off. Indeed, we find that the pairwise correlation coefficient in our sample is equal to 0.95 .

With respect to bank capital, we use the ratio of risk-based capital to risk-weighted assets and we complement it with the basic ratio of total bank capital to total assets and the ratio of Tier 1 capital to risk-weighted assets. The first ratio is the one primarily used by bank regulators, as it includes all types of capital and the element of risk weights. Accordingly, it is the one favored in our empirical analysis (for details, see Grier, 2007). ${ }^{3}$

\subsection{Control variables}

In unreported regressions we experiment with more than 200 firm-level control variables that may affect firm risk and returns (available from Compustat), loan-level variables aggregated at the firm-level (available from Thomson One Banker), and banklevel variables (available from the FDIC Call Reports). We resort to the use of variables that are theoretically motivated, are not multicollinear and show at least some statistical significance in some of the estimated models. Further, we also use a crisis dummy variable for the years 2007-2008 to capture the potential adverse effects of the subprime crisis on firm risk and performance.

At the firm level, we control for firm size, efficiency, liquidity, and age. In the literature, the effect of firm size on firms' risk and performance is ambiguous (Delis et al., 2014), with positive forces on performance stemming from economies of scale, while negative forces stemming from lack of specialization, value-destroying M\&A deals, etc. Firm efficiency (measured here by the ratio of firm sales to total assets), should be positively related with returns. However, the effect of this variable on risk is also likely to be positive, because firms with high sales to assets ratios are likely to have higher profit volatility. As a proxy for liquidity we use the so-called current ratio (ratio of current assets to current liabilities). We expect that the higher the current ratio, the lower firms' risk and the higher the performance. Also, firm age is related to shareholder and managerial experience and we expect that, if anything, this measure is positively related to firm performance. In addition to these variables we control for firm fixed effects in all our estimated equations to capture any remainder unobserved characteristics of firms.

Concerning the loan-level variables, we use the average all-inone spread of all the loans that are obtained by each firm in our sample within a specific year. We expect that higher spreads are linked to more risky and worse-performing firms because of the pricing of the higher risk premium. Further, we use a dummy variable to capture the extent to which the firm uses covenants to safeguard loan deals. We expect that these firms are in general less risky.

The last group of control variables is related to the characteristics of the lead bank of the loan syndicate. ${ }^{4}$ We experiment with many variables related to bank size, efficiency, liquidity, types of bank risk other than credit risk, but we find that most of these variables are statistically insignificant determinants of firm risk or

\footnotetext{
${ }^{3}$ Note that using this variable is, in our analysis, essentially the same with using the respective capital-buffers variable, because there have been no alternations in the minimum capital requirement during our sample period. Thus, subtracting the $8 \%$ minimum from the risk-weighted capital ratio for all available observations will not yield any changes in the empirical results or in inference.

${ }^{4}$ We do not find any effect stemming from the characteristics of the rest of the banks in the syndicate.
} 
Table 3

The effect of risk-weighted bank capital and non-performing loans on firms' performance.

\begin{tabular}{|c|c|c|c|c|c|c|c|c|}
\hline Dependent variable: & $\sigma(\mathrm{ROA})$ & Market value & Sharpe & Profitability & $\sigma(\mathrm{ROA})$ & Market value & Sharpe & Profitability \\
\hline Firm size & $\begin{array}{l}-0.007^{*} \\
(-1.68)\end{array}$ & $\begin{array}{l}0.882^{* * *} \\
(29.48)\end{array}$ & $\begin{array}{l}1.991^{* * *} \\
(3.90)\end{array}$ & $\begin{array}{l}0.006 \\
(1.28)\end{array}$ & $\begin{array}{l}-0.006^{* * *} \\
(-2.57)\end{array}$ & $\begin{array}{l}0.495^{* * *} \\
(4.57)\end{array}$ & $\begin{array}{l}1.071 \\
(0.65)\end{array}$ & $\begin{array}{l}-0.024^{*} \\
(-1.93)\end{array}$ \\
\hline Firm efficiency & $\begin{array}{l}0.002 \\
(0.84)\end{array}$ & $\begin{array}{l}-0.751^{* * *} \\
(-12.09)\end{array}$ & $\begin{array}{l}1.734^{*} \\
(1.71)\end{array}$ & $\begin{array}{l}0.027^{\text {*** }} \\
(4.98)\end{array}$ & $\begin{array}{l}0.016^{* * *} \\
(2.93)\end{array}$ & $\begin{array}{l}-0.560^{* *} \\
(-1.88)\end{array}$ & $\begin{array}{l}0.383 \\
(0.1)\end{array}$ & $\begin{array}{l}0.109^{* * *} \\
(4.89)\end{array}$ \\
\hline Firm liquidity & $\begin{array}{l}-0.000 \\
(-0.35)\end{array}$ & $\begin{array}{l}0.075^{* * *} \\
(3.06)\end{array}$ & $\begin{array}{l}-0.590^{* *} \\
(-2.00)\end{array}$ & $\begin{array}{l}0.001 \\
(0.33)\end{array}$ & $\begin{array}{l}-0.002^{* *} \\
(-1.89)\end{array}$ & $\begin{array}{l}0.026^{* *} \\
(2.48)\end{array}$ & $\begin{array}{l}0.048 \\
(0.2)\end{array}$ & $\begin{array}{l}-0.002 \\
(-0.84)\end{array}$ \\
\hline Firm age & $\begin{array}{l}0.000 \\
(0.34)\end{array}$ & $\begin{array}{l}-0.009^{* * *} \\
(-4.35)\end{array}$ & $\begin{array}{l}0.068 \\
(1.25)\end{array}$ & $\begin{array}{l}-0.000^{* *} \\
(-2.33)\end{array}$ & $\begin{array}{l}0.001^{* *} \\
(2.44)\end{array}$ & $\begin{array}{l}0.115^{\text {*** }} \\
(3.89)\end{array}$ & $\begin{array}{l}-0.390 \\
(-1.42)\end{array}$ & $\begin{array}{l}0.001 \\
(0.84)\end{array}$ \\
\hline Borrowing spread & $\begin{array}{l}0.000^{* * *} \\
(2.67)\end{array}$ & $\begin{array}{l}-0.004^{* * *} \\
(-9.64)\end{array}$ & $\begin{array}{l}-0.030^{* * *} \\
(-5.78)\end{array}$ & $\begin{array}{l}-0.000^{* * *} \\
(-4.55)\end{array}$ & $\begin{array}{l}0.000 \\
(0.53)\end{array}$ & $\begin{array}{l}-0.001^{* * *} \\
(-2.62)\end{array}$ & $\begin{array}{l}-0.010 \\
(-1.39)\end{array}$ & $\begin{array}{l}-0.000 \\
(-0.28)\end{array}$ \\
\hline General covenants & $\begin{array}{l}-0.003^{* *} \\
(-2.53)\end{array}$ & $\begin{array}{l}-0.057^{* *} \\
(-2.32)\end{array}$ & $\begin{array}{l}0.544 \\
(1.24)\end{array}$ & $\begin{array}{l}0.008^{* *} \\
(2.47)\end{array}$ & $\begin{array}{l}-0.000 \\
(-0.88)\end{array}$ & $\begin{array}{l}0.016 \\
(0.58)\end{array}$ & $\begin{array}{l}0.156 \\
(0.39)\end{array}$ & $\begin{array}{l}0.002 \\
(0.92)\end{array}$ \\
\hline Bank risk-weighted capital & $\begin{array}{l}0.075 \\
(0.63)\end{array}$ & $\begin{array}{l}-1.038 \\
(-0.74)\end{array}$ & $\begin{array}{l}3.762 \\
(0.12)\end{array}$ & $\begin{array}{l}-0.535^{* * *} \\
(-2.93)\end{array}$ & $\begin{array}{l}0.256^{* *} \\
(2.34)\end{array}$ & $\begin{array}{l}-13.061^{* * *} \\
(-3.1)\end{array}$ & $\begin{array}{l}-77.311 \\
(-0.79)\end{array}$ & $\begin{array}{l}0.126 \\
(0.3)\end{array}$ \\
\hline Bank non-performing loans & $\begin{array}{l}0.140 \\
(0.88)\end{array}$ & $\begin{array}{l}-8.805^{* *} \\
(-2.45)\end{array}$ & $\begin{array}{l}-183.531^{* *} \\
(-2.13)\end{array}$ & $\begin{array}{l}0.010 \\
(0.03)\end{array}$ & $\begin{array}{l}0.401^{* * *} \\
(2.88)\end{array}$ & $\begin{array}{l}2.387 \\
(0.2)\end{array}$ & $\begin{array}{l}-576.188^{* * *} \\
(-3.05)\end{array}$ & $\begin{array}{l}-1.579^{* * *} \\
(-2.58)\end{array}$ \\
\hline Bank size & $\begin{array}{l}0.001 \\
(0.26)\end{array}$ & $\begin{array}{l}0.021 \\
(0.90)\end{array}$ & $\begin{array}{l}0.340 \\
(0.65)\end{array}$ & $\begin{array}{l}0.004^{* *} \\
(2.04)\end{array}$ & $\begin{array}{l}-0.001 \\
(-0.72)\end{array}$ & $\begin{array}{l}0.031 \\
(0.39)\end{array}$ & $\begin{array}{l}2.232 \\
(1.51)\end{array}$ & $\begin{array}{l}0.008 \\
(1.43)\end{array}$ \\
\hline Crisis dummy & $\begin{array}{l}-0.000 \\
(-0.02)\end{array}$ & $\begin{array}{l}0.313^{* * *} \\
(3.91)\end{array}$ & $\begin{array}{l}2.186 \\
(1.23)\end{array}$ & $\begin{array}{l}0.015^{* *} \\
(1.99)\end{array}$ & $\begin{array}{l}0.003 \\
(0.82)\end{array}$ & $\begin{array}{l}-0.517^{*} \\
(-1.64)\end{array}$ & $\begin{array}{l}5.038 \\
(0.86)\end{array}$ & $\begin{array}{l}0.003 \\
(0.21)\end{array}$ \\
\hline Observations & 1913 & 1644 & 1876 & 1916 & 1913 & 1644 & 1876 & 1916 \\
\hline
\end{tabular}

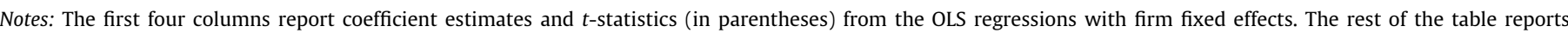

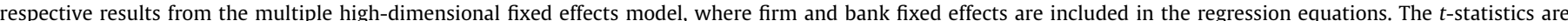

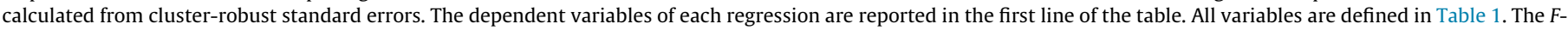

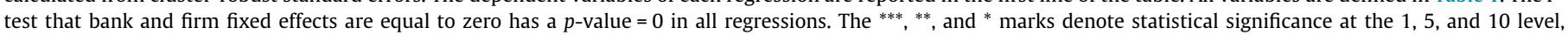
respectively.

performance. We find that bank size plays a significant role, in line with our theoretical discussion above, and thus we include the logarithm of total assets along with the bank capital and credit risk variables in the regression equations. We also use variables characterizing bank risk in general, as opposed to credit risk in particular. The most obvious measure of bank risk is the Z-score (a formal definition is provided in Table 1), which serves as a proxy for the risk of bank default or total bank risk (see e.g., Fu et al., 2014). Higher values on the $Z$-score reflect lower risk of default. Also, similar to the case of firm-level variables, we control for bank fixed effects in all the estimated equations.

\section{Empirical methodology and findings}

\subsection{Econometric identification}

Theoretically, our study is not intended to identify a causal relation of bank capital and credit risk on firm risk and performance. Instead we are interested in identifying the lending channels from risky banks to risky and non-performing firms. This implies that the direction of causality (i.e. whether it runs from banks to firms or vice versa) is not important in our study. On this front, we simply aim to identify associations and thus we can begin our analysis with simple OLS models that include firm fixed effects. However, the presence of omitted variables is very much possible and this can create a bias in our estimates of bank capital and risk.

The fact that our data set is a multilevel cross section, with specific firms making multiple loan deals with a specific lead bank, allows using bank and firm fixed effects to control for virtually all the omitted variables. ${ }^{5}$ This is a unique feature of our data set that makes econometric identification robust, as it thoroughly accounts for any omitted variables bias. Subsequently, estimation with OLS

\footnotetext{
${ }^{5}$ The time dimension is not an issue, because the loan deals are unique (not repeated in time). Thus, the bank and firm fixed effects already incorporate the information concerning any structural, regulatory and macroeconomic developments common to all banks. Indeed, if we include year fixed effects in our models we find that these fixed effects are jointly statistically insignificant. To avoid over-identification of our models, we exclude the year fixed effects. Below we do carry out additional analysis to inquire about the effect of the time dimension in our findings.
}

on this high-dimensional fixed effects model yields best linear unbiased estimates and allows avoiding instrumental variables estimators that could lead to bias due to imperfect instrumentation. The particular methodology used is thoroughly described in Gormley and Matsa (2014). Jiménez et al., 2012, 2014 use a similar identification method with multilevel data to avoid the same identification problems.

\subsection{Empirical results}

The first four columns of Table 3 report the empirical results from the OLS regressions including firm fixed effects. Non-performing loans are negative and statistically significant determinants of market value and the Sharpe ratio. Economically, a $1 \%$ point increase in non-performing loans leads to a 0.088 point reduction in the market value of firms and a 1.84 point reduction in the Sharpe ratio. These are equivalent to approximately a $1.3 \%$ reduction in the market value and a $9.07 \%$ reduction in the Sharpe ratio.

The next four columns report the empirical results from the regressions including bank non-performing loans as the measure of credit risk. In the first and the last two regressions, non-performing loans are now statistically significant at the $1 \%$ level, with a $1 \%$ point increase in non-performing loans increasing $\sigma(\mathrm{ROA})$ by 0.004 points. In other words, for the firm with a mean $\sigma(\mathrm{ROA})$ this implies an economically significant increase from 0.022 to 0.026 . The equivalent decreases in the Sharpe ratio and the ROA are also economically significant. Specifically, a $1 \%$ point increase in nonperforming loans yields a 5.8 point reduction in the Sharpe ratio (mean equals 20.3), and a 0.016 reduction in ROA (mean equals 0.12 ), all of which are sizeable effects.

The bank risk-weighted capital significantly determines $\sigma(\mathrm{ROA})$ and market value. In particular, the banks with a high risk-weighted capital ratio seem to be associated with firms with high variability of profits and low market value. ${ }^{6}$ A $1 \%$ point increase in

\footnotetext{
${ }^{6}$ We document similar results when we use the total bank capital or the Tier 1 capital ratio, except from the fact that the latter ratio has a statistically significant effect on the Sharpe ratio instead of the market value. These results are available upon request.
} 
Table 4

The effect of risk-weighted bank and loan-loss provisions on firms' performance.

\begin{tabular}{lllll}
\hline Dependent variable: & $\sigma(\mathrm{ROA})$ & $\begin{array}{l}\text { Market } \\
\text { value }\end{array}$ & Sharpe & ROA \\
\hline Firm size & $-0.006^{* * *}$ & $0.505^{* * *}$ & 0.848 & $-0.026^{* *}$ \\
& $(-2.78)$ & $(5.15)$ & $(0.45)$ & $(-2.09)$ \\
Firm efficiency & $0.016^{* * *}$ & $-0.550^{* *}$ & 0.092 & $0.109^{* * *}$ \\
& $(2.63)$ & $(-1.88)$ & $(0.03)$ & $(5.07)$ \\
Firm liquidity & $-0.002^{*}$ & $0.026^{* * *}$ & 0.127 & -0.001 \\
& $(-1.85)$ & $(2.75)$ & $(0.58)$ & $(-0.45)$ \\
Firm age & $0.001^{* *}$ & $0.075^{* *}$ & -0.279 & -0.000 \\
Borrowing spread & $(2.12)$ & $(1.97)$ & $(-1.00)$ & $(0.32)$ \\
& 0.000 & $-0.001^{* * *}$ & $-0.012^{*}$ & -0.000 \\
General covenants & $(0.93)$ & $(-3.15)$ & $(-1.64)$ & $(-0.29)$ \\
& -0.001 & 0.010 & 0.233 & 0.024 \\
Bank risk-weighted & $(-1.02)$ & $(0.33)$ & $(0.59)$ & $(1.16)$ \\
capital & $0.256^{* *}$ & $-10.567^{* *}$ & -85.755 & 0.197 \\
& $(2.47)$ & $(-2.58)$ & $(-1.00)$ & $(0.47)$ \\
Bank loan-loss provisions & $0.329^{* *}$ & $-11.566^{*}$ & -198.587 & $-1.041^{* *}$ \\
& $(2.32)$ & $(-1.79)$ & $(-1.63)$ & $(-2.06)$ \\
Bank size & -0.000 & 0.046 & 1.277 & 0.004 \\
Crisis dummy & $(-0.25)$ & $(0.57)$ & $(1.09)$ & $(0.72)$ \\
Observations & -0.001 & -0.099 & $6.022^{* *}$ & $0.018^{*}$ \\
& $(-0.35)$ & $(-1.23)$ & $(2.39)$ & $(1.76)$ \\
& 1949 & 1672 & 1912 & 1952 \\
\hline
\end{tabular}

Notes: The table reports coefficient estimates and $t$-statistics (in parentheses) from the multiple high-dimensional fixed effects model, where firm and bank fixed effects are included in the regression equations. The $t$-statistics are calculated from cluster-robust standard errors. The dependent variables of each regression are reported in the first line of the table. All variables are defined in Table 1 . The F-test that bank and firm fixed effects are equal to zero has a $p$-value $=0$ in all regressions. The ${ }^{* * *}, *^{* *}$, and ${ }^{*}$ marks denote statistical significance at the 1,5 , and 10 level, respectively.

the risk-weighted capital increases $\sigma(\mathrm{ROA})$ by approximately $0.26 \%$ points. For a firm with an average $\sigma(R O A)$ this increase is equivalent to an increase from 0.022 to 0.0276 . These results are in line with the theoretical literature on the moral hazard behavior of banks that hold higher levels of capital. In other words, the role of bank capital as a risk buffer expands the risk-bearing capacity of banks and increases incentives to lend to riskier firms (e.g., Repullo, 2004).

In Tables 4 and 5 we replicate the results of the last four columns of Table 3 , this time using loan-loss provisions and loan charge-offs as our measure of credit risk, respectively. The regressions of both tables show a qualitatively very similar picture with that of Table 3, even though the number of available observations differs substantially. Specifically, loan-loss provisions increase the $\sigma(\mathrm{ROA})$ of firms and reduce their market value and ROA. Also, the effect of a $1 \%$ point increase in loan-loss-provisions is economically smaller compared to the respective effect of non-performing loans. In turn, the loan charge-offs also increase the $\sigma(\mathrm{ROA})$ and decrease the Sharpe ratio. The economic significance of the loan charge-offs is the largest among the three bank credit-risk variables in the Sharpe-ratio equations, which is intuitive given the de facto increase in the credit risk reflected by this variable.

In Table 6 we report the results from the equations that include the bank $Z$-score instead of the bank risk-weighted capital. ${ }^{7}$ We do not include both these variables in the same equation because the $Z$ score includes information on bank capital. We only report the results based on the non-performing loans ratio as the measure of credit risk, which is also included given that credit and total bank risk are two relatively different notions. Even though these regressions have a somewhat lower number of observations, the non-performing loans ratio is the one favored by the majority of the banking

\footnotetext{
${ }^{7}$ We also use the probability of default (Fu et al., 2014) and the results are very similar.
}

Table 5

The effect of risk-weighted bank capital and loan charge-offs on firms' performance.

\begin{tabular}{|c|c|c|c|c|}
\hline Dependent variable: & $\sigma(\mathrm{ROA})$ & $\begin{array}{l}\text { Market } \\
\text { value }\end{array}$ & Sharpe & ROA \\
\hline Firm size & $\begin{array}{l}-0.006^{* *} \\
(-2.57)\end{array}$ & $\begin{array}{l}0.509^{* * *} \\
(5.04)\end{array}$ & $\begin{array}{l}0.519 \\
(0.28)\end{array}$ & $\begin{array}{l}-0.026^{* *} \\
(-2.02)\end{array}$ \\
\hline Firm efficiency & $\begin{array}{l}0.016^{* * *} \\
(2.92)\end{array}$ & $\begin{array}{l}-0.561^{*} \\
(1.90)\end{array}$ & $\begin{array}{l}0.242 \\
(0.07)\end{array}$ & $\begin{array}{l}0.109^{* * *} \\
(4.98)\end{array}$ \\
\hline Firm liquidity & $\begin{array}{l}-0.002^{*} \\
(-1.83)\end{array}$ & $\begin{array}{l}0.027^{* * *} \\
(2.93)\end{array}$ & $\begin{array}{l}0.099 \\
(0.44)\end{array}$ & $\begin{array}{l}-0.001 \\
(-0.43)\end{array}$ \\
\hline Firm age & $\begin{array}{l}0.001^{* *} \\
(2.20)\end{array}$ & $\begin{array}{l}0.076^{*} \\
(1.80)\end{array}$ & $\begin{array}{l}-0.543 \\
(-1.59)\end{array}$ & $\begin{array}{l}0.001 \\
(0.60)\end{array}$ \\
\hline Borrowing spread & $\begin{array}{l}0.000 \\
(1.06)\end{array}$ & $\begin{array}{l}-0.001^{* * *} \\
(-3.30)\end{array}$ & $\begin{array}{l}-0.010 \\
(-1.50)\end{array}$ & $\begin{array}{l}0.000 \\
(-0.82)\end{array}$ \\
\hline General covenants & $\begin{array}{l}-0.001 \\
(-1.08)\end{array}$ & $\begin{array}{l}0.010 \\
(0.32)\end{array}$ & $\begin{array}{l}0.395 \\
(1.00)\end{array}$ & $\begin{array}{l}0.002 \\
(0.97)\end{array}$ \\
\hline $\begin{array}{l}\text { Bank risk-weighted } \\
\text { capital }\end{array}$ & $\begin{array}{l}0.254^{* *} \\
(2.28)\end{array}$ & $\begin{array}{l}-11.045^{* *} \\
(-2.58)\end{array}$ & $\begin{array}{l}-35.798 \\
(-0.41)\end{array}$ & $\begin{array}{l}0.102 \\
(0.24)\end{array}$ \\
\hline Bank loan charge-offs & $\begin{array}{l}0.512^{* *} \\
(2.75)\end{array}$ & $\begin{array}{l}-13.301 \\
(-1.23)\end{array}$ & $\begin{array}{l}-712.479^{* * *} \\
(-2.76)\end{array}$ & $\begin{array}{l}-0.672 \\
(-0.85)\end{array}$ \\
\hline Bank size & $\begin{array}{l}0.000 \\
(0.02)\end{array}$ & $\begin{array}{l}0.037 \\
(0.47)\end{array}$ & $\begin{array}{l}1.016 \\
(0.86)\end{array}$ & $\begin{array}{l}0.004 \\
(0.58)\end{array}$ \\
\hline Crisis dummy & $\begin{array}{l}0.000 \\
(-0.08)\end{array}$ & $\begin{array}{l}-0.115 \\
(-1.41)\end{array}$ & $\begin{array}{l}5.184^{* *} \\
(2.23)\end{array}$ & $\begin{array}{l}0.003^{*} \\
(1.73)\end{array}$ \\
\hline Observations & 1949 & 1672 & 1912 & 1952 \\
\hline
\end{tabular}

Notes: The table reports coefficient estimates and $t$-statistics (in parentheses) from the multiple high-dimensional fixed effects model, where firm and bank fixed effects are included in the regression equations. The $t$-statistics are calculated from cluster-robust standard errors. The dependent variables of each regression are reported in the first line of the table. All variables are defined in Table 1 . The F-test that bank and firm fixed effects are equal to zero has a $p$-value $=0$ in all regressions The ${ }^{* * *},{ }^{* *}$, and ${ }^{*}$ marks denote statistical significance at the 1,5 , and 10 level respectively.

literature (e.g., Fernández and González, 2005; Bushman and Williams, 2012).

We find that the bank Z-score is positively related with firms' market value, the Sharpe ratio and the ROA and this effect is strongly statistically and economically significant. Moreover, the effect of the $Z$-score is independent of the respective effect of non-performing loans, implying that several types of bank risk other than credit risk have a direct bearing on the bank-firm relationships. Evidently, banks with a lower probability of defaults (higher Z-score) are likely to be associated with better-performing firms.

We examine the sensitivity of our results using a number of additional robustness tests (results are available on request) on the potential in-sample heterogeneity of our estimates due to other bank characteristics and macroeconomic developments. First, we examine whether the results change in the periods before and after 2007 (the year of the subprime crisis origination), by including the interaction term of our bank credit-risk and capital variables with a dummy that takes the value one in the period 2000-2006 and zero otherwise. However, these interaction terms are statistically insignificant.

Second, we examine whether there is interplay between bank credit risk and bank capital in determining firms' risk and performance. Given the finding that both bank credit risk and risk-based capital have a positive effect on the variability of returns, this is a test of the hypothesis that for banks with high capital ratios, the positive relation between bank credit risk and firms risk will be more significant for those banks with higher capital. However, this interaction term is also statistically insignificant.

Finally, we experiment with interaction terms of bank creditrisk with bank size and market power, as well as of bank capital with bank size and market power. For market power we introduce a Lerner index of market power, estimated as in Delis et al. (2014). However, even these interaction terms are found to be statistically insignificant. 
Table 6

The effect of non-performing loans and total bank risk on firms' performance.

\begin{tabular}{lllll}
\hline Dependent variable: & $\sigma(\mathrm{ROA})$ & $\begin{array}{l}\text { Market } \\
\text { value }\end{array}$ & Sharpe & ROA \\
\hline Firm size & $-0.008^{* * *}$ & $0.559^{* * *}$ & -2.569 & -0.012 \\
& $(-2.77)$ & $(5.01)$ & $(-0.62)$ & $(-1.42)$ \\
Firm efficiency & $0.023^{* * *}$ & $-1.461^{* * *}$ & -11.840 & -0.005 \\
& $(3.42)$ & $(-5.89)$ & $(-1.55)$ & $(-0.29)$ \\
Firm liquidity & -0.002 & -0.029 & $-1.042^{* *}$ & $-0.008^{* * *}$ \\
& $(-1.41)$ & $(1.15)$ & $(-2.33)$ & $(-4.90)$ \\
Firm age & $0.001^{* *}$ & $0.034^{*}$ & $-0.374^{*}$ & -0.001 \\
Borrowing spread & $(2.09)$ & $(1.64)$ & $(-1.72)$ & $(-0.84)$ \\
& 0.000 & $-0.001^{* * *}$ & -0.008 & 0.000 \\
General covenants & $(1.16)$ & $(-3.00)$ & $(-0.97)$ & $(0.23)$ \\
& $-0.001^{*}$ & 0.008 & 0.514 & 0.001 \\
Bank non-performing & $(-1.87)$ & $(0.37)$ & $(1.22)$ & $(0.56)$ \\
loans & $0.434^{* * *}$ & $-14.361^{* * *}$ & $-477.616^{* * *}$ & $-1.157^{* * *}$ \\
& & & & \\
Bank Z-score & $(2.71)$ & $(-2.67)$ & $(-3.26)$ & $(-3.25)$ \\
& -0.005 & $0.757^{* * *}$ & $8.236^{* * *}$ & $0.098^{* * *}$ \\
Bank size & $(-1.37)$ & $(6.35)$ & $(3.88)$ & $(11.27)$ \\
Crisis dummy & 0.001 & 0.029 & 0.691 & 0.002 \\
Observations & $(0.74)$ & $(0.87)$ & $(0.65)$ & $(0.59)$ \\
& -0.000 & -0.045 & $5.709^{*}$ & 0.009 \\
& $(-0.13)$ & $(-0.57)$ & $(1.91)$ & $(1.62)$ \\
& 2346 & 2078 & 2313 & 2352 \\
\hline
\end{tabular}

Notes: The table reports coefficient estimates and $t$-statistics (in parentheses) from the multiple high-dimensional fixed effects model, where firm and bank fixed effects are included in the regression equations. The $t$-statistics are calculated from cluster-robust standard errors. The dependent variables of each regression are reported in the first line of the table. All variables are defined in Table 1 . The F-test that bank and firm fixed effects are equal to zero has a $p$-value $=0$ in all regressions. The ${ }^{* * *},{ }^{* *}$, and ${ }^{*}$ marks denote statistical significance at the 1,5 , and 10 level, respectively.

\section{Conclusions and policy implications}

This article examines the profile of banks that lend to firms with higher risk and lower profitability. We use a unique data set of syndicated loans, which has two important advantages. First, it allows building a sample on bank-firm relationships where all the important observable characteristics of firms and banks are available through a merging process with other databases. Second, it represents a multilevel cross-sectional data set, with the important feature of repeated observations across firms and banks. This allows controlling for essentially all the bank and firm characteristics through the use of bank and firm fixed effects.

We examine the profile of banks in terms of their levels of credit risk and capital, which are the variables characterizing the theoretical nexus in the decision to lend in the majority of the theoretical literature. We find that banks with high credit risk de facto lend to firms with higher profit volatility, lower market value and lower profitability ratios (simple or risk-adjusted). These effects are so economically significant and document an important adverse selection mechanism in financial intermediation, whereby the risky banks are affiliated with risky and worse-performing firms. We also find that banks with relatively high levels of risk-weighted capital are associated with firms with higher volatility of returns and lower market value.

Taken together with the fact that we examine the syndicated loan market, which involves relative large banks and firms and is deemed to be quite competitive and transparent, our results have important policy implications. With respect to bank credit risk, our results show that there is a special type of a moral hazard mechanism potentially working in both directions, from firms to banks and vice versa. If this mechanism is considered as a bad equilibrium in a multiple equilibrium framework (the good one being the relationship lending between healthy banks and firms), then this is a recipe for market failure.
With respect to bank capital, our findings are in line with an important theoretical literature on the way higher levels of capital inflict adverse selection and moral hazard in the lending behavior of banks. Subsequently, this creates room for prudential supervision, whereby the bank regulators should monitor the projects undertaken by overly risky and well-capitalized banks more closely. This proposal is quite timely in light of the discussion surrounding the newly introduced leverage ratio (in terms of Tier 1 capital) under Basel III. Evidently, the emphasis on the types of bank-firm relationships, especially in large loan deals, based on credit risk is quite important in light of the higher capital requirements imposed on banks. Our results suggest that targeting credit risk more directly could enhance the soundness of the bank lending activity and could break this multiplicity of equilibria, yielding a more stable syndicated loan market. The emphasis on bank capital alone, despite promoting a safer banking environment, has the limitation that it also exacerbates the adverse selection and moral hazard problems in the market for loans.

Certainly, further analysis is needed to identify which loans (and borrowers) are very risky and which ones are required as a means to improve the growth potential of the relatively worse-performing firms. To this end, potential extensions of research include separating the firms into risky and less risky ones or analyzing the effect of bank capital and risk on the probability of firm growth or default. Identifying causal mechanisms around these relationships are clear challenges for future research.

\section{References}

Adams, R.B., Ferreira, D., 2009. Women in the boardroom and their impact on governance and performance. Journal of Financial Economics 94, 291-309.

Akerlof, G., 1970. The market for 'lemons': quality uncertainty and the market mechanism. Quarterly Journal of Economics 84, 488-500.

Bester, H., 1985. Screening vs rationing in credit markets with imperfect information. American Economic Review 75, 850-855.

Bhattacharya, S., Thakor, A.V., 1993. Contemporary banking theory. Journal of Financial Intermediation 3, 2-50.

Bushman, R.M., Williams, C.D., 2012. Accounting discretion, loan loss provisioning, and discipline of banks' risk-taking. Journal of Accounting and Economics 54, 118.

Dahl, D., Shrieves, R., 1992. The relationship between risk and capital in commercial banks. Journal of Banking \& Finance 16, 439-457.

Delis, M.D., Gaganis, C., Hasan, I., Pasiouras, F., 2014. Genetic diversity in the origin countries of board directors and corporate performance. Mimeo.

Diamond, D.W., Rajan, R.G., 2000. A theory of bank capital. Journal of Finance 55, 2431-2465.

Diamond, D.W., Rajan, R.G., 2001. Liquidity risk, liquidity creation, and financial fragility: a theory of banking. Journal of Political Economy 109, 287-327.

Dybvig, P.H., Warachka, M., 2013. Tobin's $q$ does not measure firm performance: theory, empirics, and alternative measures. Available at; <http://ssrn.com/ abstract $=1562444>$.

Fernández, A., González, F., 2005. How accounting and auditing systems can counteract risk-shifting of safety nets in banking? Some international evidence. Journal of Financial Stability 1, 466-500.

Fu, M., Lin, R., Molyneux, P., 2014. Bank competition and financial stability in the Asia-pacific. Journal of Banking and Finance 38, 64-77.

Giannetti, M., 2003. Bank-firm relationships and contagious banking crises. Journal of Money, Credit and Banking 35, 239-261.

Gormley, T.A., Matsa, D.A., 2014. Common errors: how to (and not to) control for unobserved heterogeneity. Review of Financial Studies 27, 617-661.

Gorton, G., Winton, A., 2000. Liquidity provision, bank capital, and the macroeconomy. Available at: <http://ssrn.com/abstract=253849>

Grier, W.A., 2007. Credit Analysis of Financial Institutions. Euromoney Institutional Investor Plc, London, UK.

Hellmann, T.F., Murdock, K.C., Stiglitz, J.E., 2000. Liberalization, moral hazard in banking, and prudential regulation: are capital requirements enough? American Economic Review 90, 147-165.

Hitt, M.A., Hoskisson, R.E., Kim, H., 1997. International diversification: effects on innovation and firm performance in product-diversified firms. Academy of Management Journal 40, 767-798.

Hoshi, T., Kashyap, A., Scharfstein, D., 1991. Corporate structure, liquidity, and investment: evidence from Japanese panel data. Quarterly Journal of Economics $27,33-60$.

Jiménez, G., Ongena, S., Peydró, J.L., Saurina, J., 2012. Credit supply and monetary policy: identifying the bank balance-sheet channel with loan applications. American Economic Review 102, 2301-2326. 
Jiménez, G., Ongena, S., Peydró, J.L., Saurina, J., 2014. Hazardous times for monetary policy: what do twenty-three million bank loans say about the effects of monetary policy on credit risk? Econometrica 82, 463-505.

Jokipii, T., Milne, A., 2011. Bank capital buffer and risk adjustment decisions. Journal of Financial Stability 7, 165-178.

Jones, J.D., Lang, W.W., Nigro, P.J., 2005. Agent bank behavior in bank loan syndications. Journal of Financial Research 28, 385-402.

Laeven, L., Levine, R., 2009. Bank governance, regulation and risk taking. Journal of Financial Economics 93, 259-275.

Murfin, J., 2012. The supply-side determinants of loan contract strictness. Journal of Finance 67, 1565-1601.
Peek, J., Rosengren, E.S., 2005. Unnatural selection: perverse incentives and the misallocation of credit in Japan. American Economic Review 95, 1144-1166.

Rajan, R.G., 1992. Insiders and outsiders: the choice between informed and arm'slength credit. Journal of Finance 47, 1367-1400.

Repullo, R., 2004. Capital requirements, market power, and risk-taking in banking. Journal of Financial Intermediation 13, 156-182.

Robb, A.M., Watson, J., 2012. Gender differences in firm performance: evidence from new ventures in the United States. Journal of Business Venturing 27, 544-558.

Stiglitz, J., Weiss, A., 1981. Credit rationing in markets with imperfect information. American Economic Review 71, 393-410. 